\title{
Molecular markers in cervical screening - a promise for the future
}

\section{Utilitatea markerilor moleculari în screening-ul cancerului de col uterin}

\author{
Mihaela Grigore ${ }^{*}$, Sergiu Teleman ${ }^{2}$, Didona Ungureanu ${ }^{3}$, Alina Mares ${ }^{4}$ \\ 1. University of Medicine and Pharmacy "Gr.T.Popa”, Department of Obstetrics and Gynecology, \\ Iasi, Romania \\ 2. University of Medicine and Pharmacy "Gr.T.Popa", Department of Biochemistry, Iasi, Romania \\ 3. University of Medicine and Pharmacy "Gr.T.Popa", Department of Pathology, Iasi, Romania \\ 4. Medis Medical Centre, Iasi, Romania
}

\begin{abstract}
Cervical cancer is one of the leading cancers in women worldwide. The detection and diagnosis of cervical carcinoma and its precursor lesions, called cervical intraepithelial lesions (CIN), represents the main goal in order to decrease the morbidity and mortality of this disease. In the majority of cases CIN resolve spontaneously. Only a minor part of the lesions develop to high-grade lesions and eventually invasive cancer and it is important to detect those CIN with potential to progress to cervical cancer. For clinical management it is important to distinguish the cervical dysplasia with regression potential in order to avoid unnecessary treatments. Many potential biomarkers have been analyzed for the characterization of cervical cancer and pre-cancer. So far, detection of HPV has been the most promising clinical application. Several new markers have been evaluated intensively and might be used in some clinical settings, mainly p16, MCM5/CDC6 and HPV RNA, integration of HPV DNA into the host genome, chromosomal imbalances. In this article, representative examples of these markers are presented in the context of improved cervical disease detection and progression.
\end{abstract}

Keywords: cervical cancer, cervical intraepithelial neoplasia, HPV, molecular markers, p16 marker

\section{Rezumat}

Cancerul de col uterin reprezintă unul din cele mai frecvente cancere întâlnite la femeie. Elementul cheie pentru scăderea morbiditătii şi mortalității în cancerul cervical este diagnosticul acestuia în stadii incipiente precum şi a leziunilor precanceroase numite displazii de col uterin. Displaziile de col uterin pot fi de grad redus sau de grad înalt. Un număr semnificativ dintre displaziile de grad redus regresează spontan şi doar un număr limitat progresează către leziuni de grad înalt şi cancer cervical. Pentru clinician este esențială identificarea acestora întrucât pot fi astfel evitate tratamente inutile. De-a lungul timpului au fost analizați multipli markeri care să identifice displaziile cervicale cu potenţial evolutiv. Momentan cel mai utilizat marker este reprezentat de genotiparea virală. Pe lângă acesta şi alți markeri şi-au demonstrat utilitatea în încadrarea evoluti-

${ }^{*}$ Corresponding author : Mihaela Grigore, Aleea Baltagului 7A, 700489, Iasi, Romania, Tel: +40232221515, Fax: +40232221516, E-mail: mihaela.grigore@edr.ro 
vă a leziunilor cervicale: p16, MCM5/CDC6, integrarea ADN-ului în genomul celulei gazdă. Articolul trece în revistă cei mai importanți markeri utilizați la ora actuală ilustrând cu cazuistica proprie utilizarea acestora.

Cuvinte cheie: cancer cervical, displazie de col uterin, neoplazia cervicală intraepitelială, human papilloma virus, markeri moleculari

Received: $18^{\text {th }}$ January 2013; Accepted: $12^{\text {th }}$ April 2013; Published: $15^{\text {th }}$ June 2013.

\section{Introduction}

Cervical cancer is one of the leading cancers in women worldwide. Cervical cancer develops through some precursor lesions called cervical intraepithelial lesions (CIN). Cell modifications can be classified as CIN 1,2, or 3. The majority of low grade precursor lesions (CIN 1) regress spontaneously without treatment. Only a small part of them progress to high grade lesions (CIN 2 and CIN 3) and eventually invasive cancer. According to Ostor only $10 \%$ of CIN1 will progress to CIN3 and from CIN3 only $12 \%$ will progress to invasive cancer (1).

Screening for cervical cancer is mainly based on the Papanicolaou smear (also called Pap test) and the benefit of it is demonstrated by the decreasing cervical cancer incidence over the past decades in countries that are using it. Unfortunately the Pap test has a low sensitivity and this fact require frequent retesting of women with abnormal smears. In order to improve the quality of the Pap test, liquid based cytology has been introduced. This method is characterized by more homogeneous staining cell images and less debris. However, the ability of this new method to detect more relevant high-grade cervical lesions remains to be shown in large randomized controlled trials $(2,3)$.

Screening for cervical cancer can be considered effective if precursor lesions are detected in order to be treated before cancer develops. On the other hands treatment of all precursor lesions that has in great proportion a high probability of spontaneous regression can induce an over-treatment with many side effects, emotional distress in women and unnecessary costs. Screening improvements need to address mainly the issue of reducing unnecessary follow-up of unclear or clinically nor relevant test results. In the last years a lot of research studies have been performed to develop new biomarkers for cervical cancer screening. Most of this work was related to human papilloma virus (HPV) detection because HPV is recognized as the etiologic agent responsible for the initiation of cervical neoplasia. In addition to HPV detection some promising markers have been identified by analyzing the molecular events that result in the transformation of the cervical epithelium by HPV and by studying particularly the interaction of HPV with host cell proteins (4-7).

\section{Human papilloma viruses}

HPVs are small DNA viruses that have a genome of about $8 \mathrm{~kb}$ and code for 8-10 genes. The genome of HPV encode a long control region (LCR), early proteins (E1-E8) and late proteins (L1-L2) and their functions are presented in Table 1 (8). At present, more than 100 different HPV types have been identified. They differ significantly in carcinogenic potential (9). The oncogenic forms of HPV (including types 16 and 18) are associated with cervical carcinoma. In most cases, HPV infections are transient, with $70 \%$ of newly infected individuals clearing the virus within 1 year and $90 \%$ of them showing no trace of HPV within 2 years (10). Persistent infection causes the greatest risk and is probably enhanced with highrisk types of HPV (11).

\section{HPV life cycle, HPV oncogenes}

The molecular interactions between viral and cellular genes have been studied largely in the last two decades. Two genes were found to be mostly responsible for the development of the disease. At present, two HPV proteins E6 and E7 
Table 1. The functions of the HPV genes

\begin{tabular}{ll}
\hline HPV genes & \multicolumn{1}{c}{ Function } \\
\hline LCR & Regulatory control of transcription, replication and host interactions \\
L1 & Major capsid protein \\
02.07.09 & Minor capsid protein \\
E1 & Viral replication and maintenance of viral episome \\
E2 & Transcriptional regulation and cofactor for replication \\
E3 & $? ? ?$ \\
E4 & Keratin interactions and signal tranduction \\
E5 & Growth factor receptor interactions and signal transduction \\
E6 and E7 & Prolongs division phase of the cell cycle to promote replication \\
& Responsible for malignant transformation of the cervical keratinocyte \\
E8 & following infection with oncogenic subtypes of HPV \\
\hline
\end{tabular}

were found to interact and block p53 and pRB in infected cells (12). Loss of pRB function leads to cell cycle activation. Normally, uncontrolled cell cycle activation induced by E7 is counteracted by cellular apoptosis. However, this pathway is blocked by E6 mediated p53 degradation. The sign of progression is the altered expression pattern of HPV oncogenes. In high-grade lesions, E6 and E7 are strongly expressed in basal epithelial cells. In basal cells, under the control of E6 and E7 the tight replication control is lost and the cells start to proliferate and gain transforming mutations. Initiation of cellular replication is under the control of a protein complex which has two main components: MCM5 and CDC5. These two components are over-expressed in replicating cells transformed by high-risk HPV (13). Other early effect of E6 and E7 expression in basal cells is the induction of chromosomal instability which result in breaks, lagging and altered distribution of chromosomes $(14,15)$. Based on the above pathogenesis of cervical intraepithelial lesions, potential biomarkers can be divided in two main categories: viral and cellular. It is important to realize that different biomarkers may serve different goals: markers for early detection (such as HPV DNA) or markers for pre-malignant lesions with potential risk to progression (such as Ki-67).

\section{Viral markers}

Methods for HPV DNA or RNA detection are expected to improve cervical cancer screening protocols. Several methods are available to detect HPV. The first methods used for HPV detection were based on DNA hybridization but they have limited sensitivity and are too complex in order to be used in clinical settings. The main HPV testing methods that have well defined clinical applications at present are polymerase chain reaction (PCR) and Hybrid Capture II (HC2). Real-time PCR and mRNA testing are techniques of growing interest $(16,17)$. The clinical applications of HPV DNA or RNA detection are in the triage of borderline Pap smears and in the follow-up after treatment for cervical premalignant lesions. Primary screening using HPV is under discussion because of great distribution of HPV in young women. In any case for women over 30 years, primary screening with HPV testing could be effective (18). However, since most HPV infections resolve spontaneously and only very few of the infected women finally develop clinically relevant lesions, one positive HPV test does not justify medical interventions at once, but rather identifies women who have elevated risk as long as the infection persists (18). 
HPV integration. The development of cervical cancer is preceded by the shift in HPV gene expression towards high-oncogenic expression. This change can be detected by altered mARN and protein expression of HPV genes. E6 and E7 are strongly expressed in high-grade lesions. An important finding is detection of integration of HPVDNA into the cellular genome of the host $(19,20)$. HPV integration reveals high-grade lesions with a very high potential for progress and which require treatment instead of monitoring. Also, HPV integration is considered a very specific marker in post-treatment and recurrence surveillance.

\section{Cellular markers}

The potentially promising markers can be categorized into different classes such as chromosomal anomalies, cell cycle check points, tumor suppressor gene expression, apoptotic markers, angiogenetic parameters, epigenetic regulations such as methylation, metabolic markers and imaging markers. The advantages of one marker over the others and their clinical implications in cervical cancer screening are intensely studied at the moment.

Ki67/MIB-1. Dysplastic cells show increased cell cycling. Therefore, markers of cell proliferation might be a logical choice as biomarkers for CIN. Ki67 and MIB-1 are markers of proliferation and they are strongly expressed in CIN lesions, but they can also be expressed in normal basal cells that have proliferation capacity (21-23).

MYC. This oncogene is frequently amplified and over expressed in cervical cancer. It was also demonstrated, using PCR that MYC levels are increased in precancerous lesion and the levels increased with the grade of the CIN (24).

p16INK4a. The inhibition of cell cycle regulatory proteins by E6 and E7 is known to initiate the carcinogenesis process. The p16 is a cell cycle regulatory protein which is the main target of HPV. p16 is an inhibitor of CDKs 4 and 6 and functions in the progression from $\mathrm{G} 1$ to $\mathrm{S}$ phase of the cycle cell. In HPV infection with high-risk types, p16 is over expressed in high-grade lesion and also in cervical carcinoma (25). The p16 protein can be detected in both histology specimens as well as liquid-bases cytology (26). Over-expression of p16 is correlated with HPV type 16 and 18 and can be detected in both squamous cell carcinoma and adenocarcinoma $(27,28)$.

In biopsies of suspicious cervical lesions p16 is used to discriminate the low grade lesions with potential to progress to high-grade lesions (29-31). Also p16 could help to recognize underestimated cervical intraepithelial neoplasia (CIN) in women positive for high-risk human papillomavirus (HR-HPV) with negative biopsy (33). In cytology p16 is used to triage ASCUS and LSIL cases for high grade CIN with higher specificity than HPV testing (Figures 1 and 2). A practical limitation to the use of p16 as a cytological diagnostic adjunct, however is that sporadic expression of this marker is sometimes present in scattered benign endocervical glandular cells and in tuboendometrial metaplasia of the cervical mucosa, which could lead to false positive results $(34,35)$.

Survivin. Another independent marker of high-risk HPV type is survivin, a member of the family of human apoptosis inhibitors. Survivin might be an early predictor of cervical carcinogenesis. Branca et al. (36) established a linear relationship between the intensity of survivin expression and the grade of CIN. Also, in cervical cancer, survivin expression can be correlated with clinical stage and lymph node metastases $(37,38)$.

Phosphatase and tensine homologue (PTEN). This antioncogene is negatively correlated with survivin expression in CIN and cervical cancer. PTEN expression in squamous cell carcinoma is lower compared with normal cervical epithelium. It might be used as a marker for early diagnosis and prognosis of cervical cancer (37).

Telomerase. Increased telomerase activity was found in cervical dysplasia with varying sensitivity for the detection of CIN3 $(39,40)$. Fluorescence in situ hybridization (FISH) detection of telomerase RNA gene amp- 


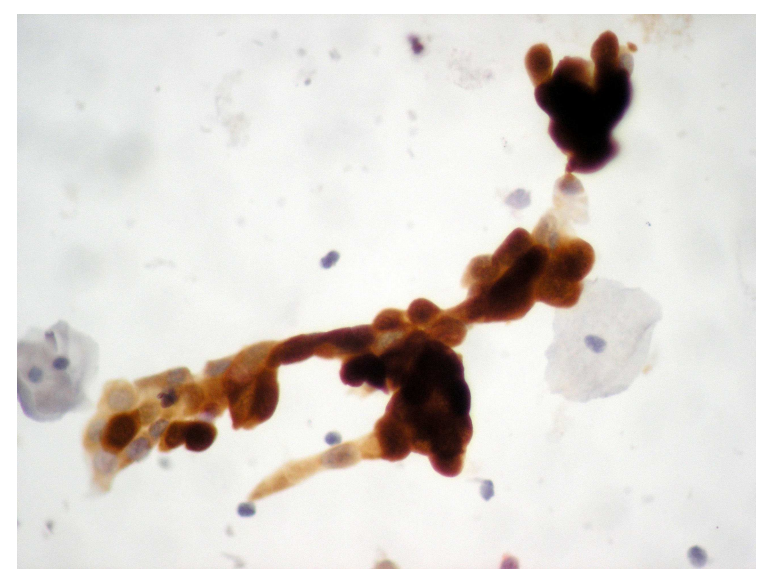

Figure 1. Biomarker p16INK4a expression in highgrade squamous intraepithelial lesions in cervical cytology specimens (DABX40).

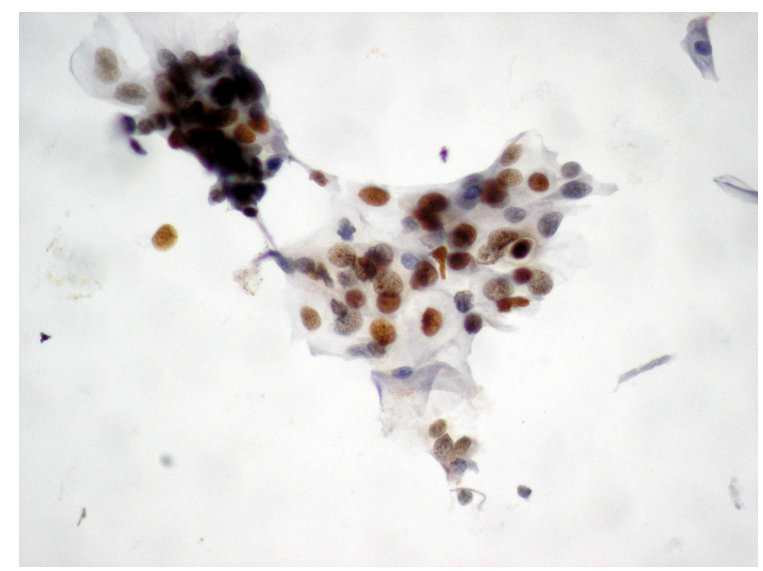

Figure 3. Biomarker ProEx C expression in highgrade squamous intraepithelial lesions in cervical cytology specimens (DABx40).

lification is useful for differential diagnosis of low- and high-grade cervical disorders $(41,42)$.

The mini chromosome maintenance (MCM). Is a class of proteins of the DNA pre-replication complex. Early publications have shown that the MCM proteins and in particular MCM5 are useful for detection of cervical diseases. The detection of MCM5 expression is not confined to high-grade cervical disease and is also detected in low-grade dysplasia and proliferative cells that have re-entered the cell cycle following infection

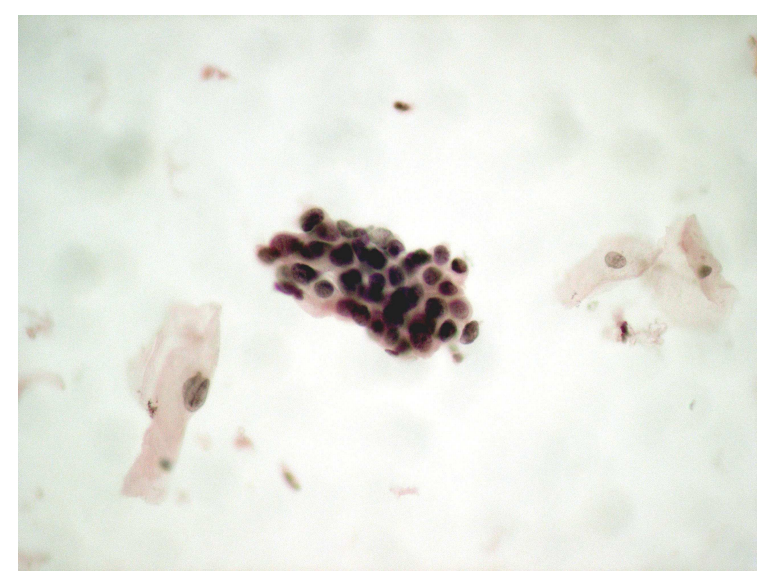

Figure 2. Biomarker p16INK4a expression in atypical squamous metaplasia incervical cytology specimens (DAB X40).

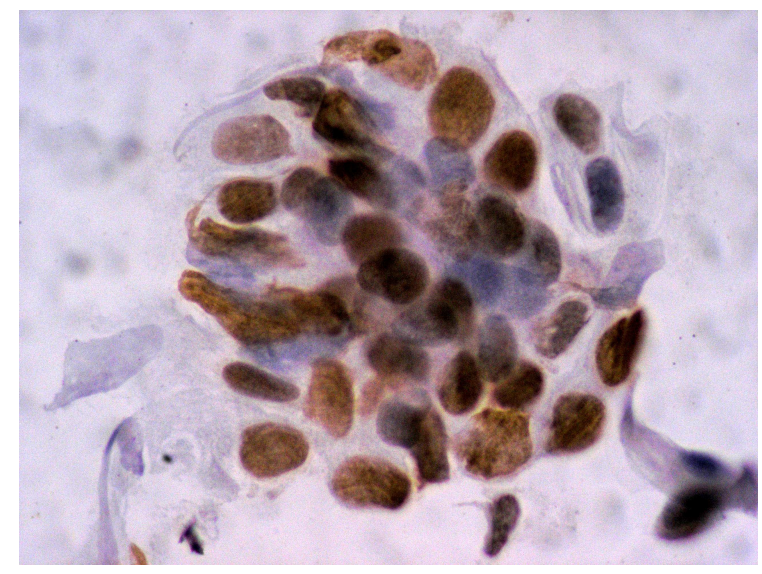

Figure 4. Biomarker ProEx C expression in highgrade squamous intraepithelial lesions in cervical cytology specimens (DABX100).

with high-risk HPV. In addition to MCM-5, others members from the MCM family (MCM2, MCM7, MCM6) have been shown to be potentially useful markers for the detection of CIN. Recent results have shown that MCM-7 appears to be a specific marker for the detection of high-grade cervical disease using immunochemistry formats (43).

Topoisomerase II- $\boldsymbol{\alpha}$ (TOP2A). Is over expressed in cervical diseases. As mentioned above the oncoproteins E6 and E7 contribute to the active induction of S-phases genes and DNA replication 
outside the normal control mechanisms of the cell cycle. Key proteins like MCM and TOP2A are expressed during this aberrant gene transcriptional activation. This behavior appears to be a hallmark within high-grade cervical disease and provides the link between infections with oncogenic HPV viral subtypes and the molecular behavior of cervical disease. Using this approach, MCM-6, MCM-4 and TOP2A have been identified as over expressed genes in CIN. Preliminary results have shown that the genes identified from micro-array analysis, such as MCM-6 and TOP2A, encode proteins that are over expressed in cervical diseases $(44,45)$. Recent studies reveal other promising candidates for CIN detection: IGFBP-3 and claudins 1 and 7 (46).

ProExC antibody is a novel biomarker cocktail containing antibodies against topoisomerase II alpha and mini chromosome maintenance 2 proteins. ProExC is a valuable marker for distinguishing dysplastic squamous and endocervical lesions of the cervix from squamous metaplasia (Figures 3 and 4). ProExC may eventually be used in conjunction with morphologyand human papillomavirus evaluation for better classification of indeterminate cervical lesions in Papanicolaou smears $(47,48)$.

Aneuploidy, chromosomal imbalances. Different studies have shown that aneuploidy precedes HPV integration in advanced CIN lesions (15). The most important alteration present in CIN is located on chromosome $3 \mathrm{q}$, and this alteration is strongly associated with the progression from severe dysplasia to invasive cancer $(49,50)$.

p53 and pRB. There are the targets of HPV oncogenes E6 and E7. Loss of p53 and pRB represents and indirect sign of HPV E6 and E7 expression. Unfortunately this loss is not specific for HPV and is present also in other tumors. In HPV infection a low frequency of p53 and pRB is associated with a higher risk of progression (51).

Methylation. In normal cells, DNA methylation plays a role in maintaining genome stability and in regulating gene expression. DNA methylation changes are an early event in carcinogenesis and are often present in the precursor lesions of various cancers. Such changes might therefore be used as markers of cervical neoplasia, either alone or in conjunction with cytology and/or HPV testing. The published data on these genes is highly heterogeneous. Three markers (DAPK1, CADM1, and RARB) showed elevated methylation in cervical cancers consistently across studies. There is currently no methylation marker that can be readily translated for use in cervical cancer $(52,53)$.

Cyclins. Are regulatory proteins involves in cell cycle regulation. A strong association was found between Cyclin E and HPV induced cell changes (54). Cyclins A and B have been shown to be over expressed in cervical adenocarcinoma and its malignant precursors (55). To date, none of the cyclins that are over expressed in HPV-induced neoplasia has sufficient sensitivity or specificity in order to be used as an independent molecular marker for the accurate detection of highgrade cervical neoplasia.

Angiogenetic markers. Apart from apoptosis, the progression of CIN is accompanied by angiogenesis and cell proliferation. Obermair et al. (56) demonstrated that angiogenetic parameters such as microvessel density and the expression of vascular endothelial growth factor (VEGF) increase with the grade of CIN. CIN 3 lesions have significantly higher microvessel density and a more intense expression of VEGF protein than normal epithelium and CIN 1 lesions $(56,57)$. This data suggest that angiogenesis might be used as a prognostic factor in patients with squamous cell carcinoma.

nm23-H1. Recently, a great interest was shown to the nm23 family of metastases-associated genes, focusing on human nm23-H1 as a potential antimetastatic gene in cervical cancer. The studies (58) report an inverse relationship between nm23$\mathrm{H} 1$ expression and CIN grade, reduced expression being associated with CIN3 or invasive cancer.

\section{Conclusion}

The difficulties of morphology-based diagnosis of cervical lesions will be addressed in the near future by the use of molecular markers. 
Their main purpose will be detection of CIN 1 with potential to progress to CIN 2 and 3. Until now, a number of potential markers have been identified. Among them, the most important are: HPV detection, p16, MCM5/CDC6 and ProExC.

\author{
Abbreviations \\ CIN-cervical intraephitelial lesion \\ HC2-Hybrid Capture II \\ HPV-human papilloma virus \\ LCR-long control region \\ PCR-polymerase chain reaction \\ PTEN-Phosphatase and tensine homologue \\ VEGF-vascular endothelial growth factor.
}

\section{Conflict of interest}

The authors declare no conflict of interest.

\section{References}

1. Ostor AG. Natural history of cervical intraephitelial neoplasia: a critical review. Int J Gynecol Pathol. 1993; 12(2):186-92

2. Davey E, Barrat A, Irwing L, Chan SF, Macaskill P, Mannes P. Effect of study design and quality on unsatisfactory rates, cytology classifications and accuracy in liquid-based versus conventional cervical cytology: a systematic review. Lancet. 2006; 367(9505):122-32

3. Confortini M, Bergeron C, Desai M, Negri G, Dalla Palma P, Montanari G, et al. Accuracy of liquid-based cytology: comparison of the results obtained within a randomized controlled trial (the New Technologies for Cervical Cancer Screening Study) and an external group of experts. Cancer Cytopathol. 2010 Aug 25;118(4):203-8.

4. Yim E-K, Park J-S. Biomarkers in Cervical Cancer. Biomark Insights. 2007 Feb 7;1:215-25.

5. von Knebel Doeberitz M. New markers for cervical dyspalsia to visualize the genomic chaos created by aberrant oncogenic papilomavirus infections. Eur J Cancer. 2002; 38(17):2229-42

6. Koskimaa HM, Kurvinen K, Costa S, Syrjanen K, Szrjanen S. Molecular markers implicating early malignant events in cervical carcinogenesis. Cancer Epidemiol Biomarkers Prev. 2010; 19(8)2003-12. Epub 2010 Jul 20

7. Malinowski D. Molecular diagnostic assays for cervical neoplasia: emerging markers for the detection of high-grade cervical disease. Biotechniques. 2005; Suppl: $17-23$

8. zur Hausen H. Papillomaviruses causing cancer: evasion from host-cell control in early events in carcinogenes- is. J Natl Cancer Inst. 2000; 92(9):690-8

9. Naucler P, Ryd W, Törnberg S, Strand A, Wadell G, Hansson BG, et al. HPV type-specific risks of high-grade CIN during 4 years of follow-up: a population-based prospective study. Br. J. Cancer. 2007 Jul 2;97(1):129-32.

10. Moscicki AB, Shiboski S, Broering J. The natural history of human papillomavirus infection as measured by repeated DNA testing in adolescent and young women. J Pediatr. 1998; 132:277-84

11. Goldie SJ, Grima D, Kohli M, Wright TC, Weinstein M, Franco E. A comprehensive natural history model of HPV infection and cervical cancer to estimate the clinical impact of a prophylactic HPV-16/18 vaccine. Int. J. Cancer. 2003 Oct 10;106(6):896-904.

12. Snidjers PJ, Steenbergen RD, Heideman DA, Meijer CJ. HPV mediated cervical carcinogenesis: conceps and clinical implications. J Pathol. 2006 Jan; 208(2):152-64

13. Wentzensen N, Vinokurova S, von Knebel Doeberitz M. Molecular markers of cervical squamous cell cancer precursor lesions. J Gynec Oncol. 2006; 11:30-40

14. Duensing S, Munger K. The human papillomavirus type 16 E6 and E7 oncoproteins independently induce numerical and structural chromosome instability. Cancer Res. 2002;62(23):7075-82

15. Melsheimer P, Vinokurova S, Wentzensen N, Bastert G, von Knebel Doeberitz M. DNA aneuploidy and integration of human papillomavirus type 16e $7 / \mathrm{e} 7$ oncogenes in intraepithelial neoplasia and invasive squamous cell carcinoma of the cervix uteri. Clin Cancer Res. 2004; 10(9)3059-63

16. Koliopoulos G, Valasoulis G, Zilakou E. An update review on HPV testing methods for cervical neoplasia. Expert Opinion on Medical Diagnostics. 2009;3(2):123-31.

17. Schiffman M, Wentzensen N, Wacholder S, Kinney W, Gage JC, Castle PE. Human papillomavirus testing in the prevention of cervical cancer. J. Natl. Cancer Inst. 2011 Mar 2;103(5):368-83.

18. Cuzick J, Szarewski A, Cubie H, Hulman G, Kitchener H, Luesley D. Management of women who test positive for high-risk types of human papillomavirus: the HART study. Lancet. 2003; 362(9399):1871-6.

19. Wetnzensen N, Vinokurova S, von Knebel Doeberitz M. Systematic review of genomic integration sites of human papillomavirus genomes in epithelial dysplasia and invasive cancer of the female genital tract. Cancer Res.2004; 64(11): 3878-84

20. Pett M, Coleman N.Integration of high-risk human papillomavirus: a key event in cervical carcinogenesis? J Pathol.2007; 212(4):356-67

21. Goel MM, Mehrotra A, Singh U, Gupta HP, Misra JS. MIB-1 and PCNA immunostaining as a diagnostic adjunct to cervical Pap smear. Diagn. Cytopathol. 2005 Jul;33(1):15-9.

22. Pirog EC, Baergen RN, Soslow RA, Tam D, DeMattia AE, Chen YT. Diagnostic accuracy of cervical low grade squamous intraephitelial lesions is improved with 
MIB-1 immunostaining. Am J Surg Pathol. 2002; 26(1):70-5

23. Brown CA, Bogers J, Sahebali S, Depuydt CE, De Prins F, Malinowski DP.Role of Protein Biomarkers in the Detection of High-Grade Disease in Cervical Cancer Screening Programs.J Oncol. 2012; 2012: 289315, doi:10.1155/2012/289315

24. Golijow CD, Abba MC, Mouron SA, Gomez MA, Dulout FN. C-myc gene amplification detected in preinvasive intraephitelial neoplasia. Int $\mathrm{J}$ Gynecol Cancer. 2001; 11(6):462-5

25. Klaes R, Friedrich T, Spitkovsy D, Ridder R., Rudy $\mathrm{U}$, Petry $\mathrm{G}$ et al. Overexpression of p16ink4A as a specific marker for dysplastic and neoplastic epithelial cells of the cervix uteri. Int J Cancer. 2001; 92:276-84

26. Sahebali S, Depuydt CE, Segers K, Moeneclay AJ, Vereecken AJ, Van Marck E, et al. P16INK4A as an adjunct marker inliquid-based cervical cytology. Int J Cancer. 2004; 108:871-6

27. Tringler B, Gup CJ, Singh M, Groshong S, Shroyer $\mathrm{AL}$, Heinz DE et al. Evaluation of p16INK4A and pRB expression in cervical squamous and glandular neoplasia. Hum Pathol. 2004; 35:689-96

28. Schorge JO, Lea JS, Elias KJ, Rajanbabu R, Coleman RL, Miller DS et al. P16INK4A as a molecular biomarker of cervical adenocarcinoma. Am J Obstet Gynecol. 2004; 190:668

29. Passamonti B, Gustinucci D, Recchia P, Bulletti S, Carlani A, Cesarini E, et al. Expression of p16 in abnormal pap-tests as an indicator of CIN2+ lesions: a possible role in the low grade ASC/US and L/SIL (Ig) cytologic lesions for screening prevention of uterine cervical tumours. Pathologica. 2010; 102(1): 6-11

30. Sung CO, Kim SR, Oh YL, Song SY. The use of p16 (INK4A) immunocytochemistry in "Atypical squamous cells which cannot exclude HSIL" compared with "Atypical squamous cells of undetermined significance" in liquidbased cervical smears. Diag.Cytopathol. 2010; 38(3):16871

31. Klaes R, Benner A, Freidrich T, Ridder R, Herrington S, Jenkins D. p16INK4a immunohistochemistry improves interobserver agreement in the diagnosis of cervical intraephitelial neoplasia. Am J Surg Pathol.2002; 26(11):1389-99

32. Lee S, Kim H, Kim H, Kim C, Kim I.The Utility of p16INK4a and Ki-67 as a Conjunctive Tool in Uterine Cervical Lesions.Korean J Pathol. 2012 June; 46(3): 253260

33. Ordi J, Garcia S, delPino M, Landolfi S, Alonso I, Quito L, et al.p16 INK4a immunostaining identifies occult $\mathrm{CIN}$ lesions in HPV-positive women. Int $\mathrm{J}$ Gynecol Pathol. 2009; 28(1):90-7.

34. Carozzi F, Cecchini S, Confortini M, Becattini V, Cariaggi MP, Pontenani G. Role of p16 expression in identifying CIN2 or more severe lesions among HPV-positive patients reffered for colposcopy after abnormal cyto- logy. Cancer. 2006 Apr 25; 108(2):119-23

35. Tringler B, Gup CJ, Shroyer KR. Correlation between $\mathrm{p} 16$ and $\mathrm{pRb}$ expression in cervical squamous and glandular neoplasia. Human Pathol. 2004; 35:689-96 36. Branca M, Giorgi C, Santini D, Di Bonito L, Ciotti M, Costa S et al; HPV-Pathogen ISS Study Group. Survivin as a marker of cervical intraepithelial neoplasia and high-risk human papillomavirus and a predictor of virus clearance and prognosis in cervical cancer. Am J Clin Pathol. 2005 Jul;124(1):113-21

37. Lu D, Qian J, Yin X, Xiao Q, Wang C, Zeng Y. Expression of PTEN and survivin in cervical cancer: promising biological markers for early diagnosis and prognostic evaluation. Br J Biomed Sci. 2012;69(4):143-6.

38. Wu SF, Zhang JW, Qian WY, Yang YB, Liu Y, Dong $\mathrm{Y}$ et al. Altered expression of survivin, Fas and FasL contributed to cervical cancer development and metastasis. Eur Rev Med Pharmacol Sci. 2012 Dec;16(15):2044-50.

39. Ault KA, Allen HK, Phillips SL, Zimmerman MB, Klingelhitz AJ. Telomerase activity as a potential diagnostic marker for triage of abnormal Pap smears. J Low Genit Tract Dis. 2005; 9(2):93-9

40. Barbosa LC, da Silva ID, Correa JC, Ribalta JC. Survivin and telomerase expression in the uterine cervix of women with human papillomavirus-induced lesions. Int $\mathbf{J}$ Gynecol Cancer. 2011; 21(1):15-21

41. Tu Z, Zhang A, Wu R, Jiang J, Li Y, Wulan N et al. Genomic amplification of the human telomerase RNA gene for differential diagnosis of cervical disorders. Cancer Gent Cytogenet. 2009; 191(1):10-16

42. Porika M, Tippani R, Mohammad A, Bollam SR, Panuganti SD, Abbagani S. Evaluation of serum human telomerase reverse transcriptase as a novel marker for cervical cancer. Int J Biol Markers. 2011; 26(1):22-6

43. Samson SJ, Parker MR, Hessling JJ, Prpic DK, Hall L, Taylor AJ. Data comparison of three molecular markers (MCM7, p16 and integrin beta) for the detection of cervical dysplasia in SurePath cytology specimens.Acta Cytol.2004; 43:658

44. Dilinuer A, Azar A, Colgan T, Nanji S. A Pilot Evaluation of a Novel Immunohistochemical Assay for Topoisomerase II- $\alpha$ and Minichromosome Maintenance Protein 2 Expression (ProEx C) in Cervical Adenocarcinoma In Situ, Adenocarcinoma, and Benign Glandular Mimics. Int J Gynecol Pathol.2009;28(2):114-9

45. Sanati S, Huettner P, Ylagan LR. Role of ProExC: a novel immunoperoxidase marker in the evaluation of dysplastic squamous and glandular lesions in cervical specimens. Int J Gynecol Pathol.2010; 29(1):79-97

46. Baege AC, Disbrow GL, Schlegel R. IGFBP-3, a marker of cellular senescence, is overexpressed in human papillomavirus-immortalized cervical cells and enhances IGF-1 mitogenesis. J Virol.2004; 78:5720-7

47. Guo M, Baruch AC, Silva EG, Jan Yj, Lin S, Sneige $\mathrm{N}$, et al. Efficacy of p16 and ProExC immunostaining in the detection of high-grade cervical intraepithelial neo- 
plasia and cervical carcinoma. Am J Clin Pathol.2011 feb; 135(2):211-20

48. Sanati S, Huettner P, Ylagan LR. Role of ProExC: a novel immunoperoxidase marker in the evaluation of dysplastic squamous and glandular lesions in cervical specimens. Int J Gynecol Pathol. 2010 Jan; 29(1):79-87.

49. Heselmeyer-Haddad K, Sommerfeld K, Schrock E, duMS, Blegen H, Shah K, Steinbeck R. Gain of chromosome $3 \mathrm{q}$ defines the transition from severe dysplasia to invasive carcinoma of the uterine cervix. Proc Natl Acd Sci USA. 1996; 93(1):479-84

50. Vazquez-Mena O, Medina-Martinez I, Juarez-Torres E, Barron V, Espinosa A, Villegas-Sepulveda N. Amplified genes may be overexpressed, unchanged, or down regulated in Cervical Cancer Cell Lines. PLoS One. 2012; 7(3): e32667

51. Mathevet P, Frappart L, Hittelman W. [Cervix dysplasias: study of $\mathrm{Rb}$ and $\mathrm{p} 53$ gene expression and correlation with mitotic activity]. Gynecol Obstet Fertil. 2000 Jan;28(1):44-50.

52. Wentzensen N, Sherman NE, Schiffman M, Wang SS.Utility of methylation markers in cervical cancer early detection: appraisal of the state-of-the-science. Gynecol Oncol. 2009; 112(2):291-2

53. Yang N, Nijhuis ER, Volders HH, Eijsink JJ, Lendvai A, Zhang B, et al. Gene promoter methylation patterns throughout the process of cervical carcinogenesis. Cell Oncol. 2010; 32(1-2): 131-43.

54. Weaver EJ, Kovatich AJ, Bibbo M. Cyclin E expression and early cervical neoplasia in Thin Prep specimens. A feasability study. Acta Cytol. 2001; 25(7):884-91

55. El-Ghobashy AA, Shaaba AM, Herod J, Innes J, Prime W, Herrington CS. Overexpression of cyclins A and $\mathrm{B}$ as markers of neoplastic glandular lesions of the cervix uteri. Gynecol Oncol. 2004; 92:628-34

56. Obermair A, Bancher-Todesca D, Bilgi S, Kaider A, Kohlberger P, Müllauer-Ertl S et al. Correlation of vascular endothelial growth factor expression and microvessel density in cervical intraepithelial neoplasia. J Natl Cancer Inst. 1997 Aug 20;89(16):1212-7

57. Ozalp S, Yalcin OT, Oner U, Tanir HM, Acikalin M, Sarac I. Microvessel density as a prognostic factor in preinvasive and invasive cervical lesions. Eur J Gynaecol Oncol. 2003;24(5):425-8

58. Branca M, Giorgi C, Ciotti M, Santini D, Di Bonito L, Costa S et al; HPV-Pathogen Istituto Superiore di Sanità Study Group. Down-regulated nucleoside diphosphate kinase $\mathrm{nm} 23-\mathrm{H} 1$ expression is unrelated to high-risk human papillomavirus but associated with progression of cervical intraepithelial neoplasia and unfavourable prognosis in cervical cancer. J Clin Pathol. 2006 Oct;59(10):1044-51. 